\title{
Alkalizing potential and calcium release of residues from intracanal dressing containing calcium hydroxide
}

\author{
Potencial de alcalinização e liberação de cálcio de resíduos de medicação intracanal contendo \\ hidróxido de cálcio
}

\author{
Mariana Pires CRESPO ${ }^{a}$, Kamila de Figueiredo PEREIRA ${ }^{\text {b* }}$, Milton Carlos KUGA ${ }^{\text {b }}$, \\ Thiago Soares PORTO ${ }^{c}$, Luciana ARMADA ${ }^{a}$
}

\begin{abstract}
âniversidade Estácio de Sá, Curso de Odontologia, Departamento de Endodontia, Rio de Janeiro, RJ, Brasil bUNESP - Universidade Estadual Paulista, Faculdade de Odontologia de Araraquara, Departamento de Odontologia Restauradora, Araraquara, SP, Brasil

'Case Western Reserve University, School of Dental Medicine, Department of Comprehensive Care, Cleveland, Ohio, United States of America
\end{abstract}

\begin{abstract}
Resumo
Introdução: Se a restauração temporária, que sela o canal radicular contra o meio bucal, falhar ou solubilizar, a medicação intracanal pode ser parcialmente removida, diminuindo a eficiência do hidróxido de cálcio $(\mathrm{CH})$. Objetivo: Avaliar o potencial alcalinizante e a liberação de íons cálcio de resíduos de diferentes medicações intracanal, em diferentes períodos. Material e método: Incisivos humanos foram endodonticamente instrumentados e divididos aleatoriamente $(\mathrm{n}=10)$. Os canais radiculares foram preenchidos com: $\mathrm{G} 1-$ Hidróxido de cálcio $(\mathrm{CH})$; $\mathrm{G} 2-\mathrm{CH}$ com $0.4 \%$ de digluconato de clorexidina ( $\mathrm{CHC}$ ); $\mathrm{G} 3-\mathrm{CH}$ com paramonoclorofenol camforado e glicerina (HPG); G4-CH mantido durante todo experimento, como controle positivo (PC) e G5-Sem medicação intracanal, como controle negativo (NC). Os espécimes foram imersos em água destilada durante 7 dias. A medicação intracanal foi removida dos grupos experimentais com um instrumento F1 (Protaper). Os dentes foram armazenados em água destilada por 24 horas, 7, 14 e 28 dias. Os dados foram submetidos aos testes ANOVA one-way e Tukey. Resultado: Todos os grupos experimentais tiveram redução no potencial alcalinizante e na liberação dos íons cálcio, quando comparados ao controle positivo $(\mathrm{p}<0.05)$. Não houve diferença estatisticamente significante entre os grupos experimentais, independente do período ( $p>0.05$ ). Conclusão: $\mathrm{O}$ potencial alcalinizante e a liberação de íons cálcio dos resíduos de diferentes medicações intracanal, em diferentes períodos, foram similares entre si e menores que o controle positivo, onde a medicação foi mantida dentro do canal radicular, encorajando a sua troca quando a restauração falhar.
\end{abstract}

Descritores: Curativos biológicos; hidróxido de cálcio; clorexidina; endodontia.

\begin{abstract}
Introduction: If the restoration, that seal the root canal from oral environment, failed or solubilize, the intracanal dressing could be partially removed, decreasing the efficiency of calcium hydroxide $(\mathrm{CH})$. Objective: To evaluate the alkalizing potential and calcium ions release of intracanal residues from different medications, in different periods. Materials and method: Human incisors were endodontically instrumented and randomly divided $(\mathrm{n}=10)$. The root canals were filled with: G1-Calcium hydroxide $(\mathrm{CH})$; $\mathrm{G} 2-\mathrm{CH}$ with $0.4 \%$ chlorhexidine digluconate $(\mathrm{CHC})$; $\mathrm{G} 3-\mathrm{CH}$ with camphorated paramonochlorophenol and glycerin (HPG); G4-CH was maintained during all experiment, as positive control group (PC) and G5-No medication was performed in the negative control group (NC). The specimens were immersed in distilled water for 7 days. The intracanal dressing was removed from the experimental groups using F1 instrument (Protaper). The teeth were stored in distilled water for 24 hours, 7,14 and 28 days. $\mathrm{pH}$ value and calcium ions released were evaluated and the data were submitted to ANOVA one-way and Tukey tests. Result: All experimental groups presented lower alkalizing potential and calcium ions release than $\mathrm{PC}(\mathrm{P}<0.05)$. No significant difference was found among the experimental groups, regardless of the period $(\mathrm{P}>0.05)$. Conclusion: The alkalizing potential and calcium ions release of residues from different intracanal dressing, in different periods, were similar and lower than the positive control group, that the medication was maintained inside the root canal, encouraging the replacement of intracanal dressing when the restoration fail.
\end{abstract}

Descriptors: Intracanal dressing; calcium hydroxide; chlorhexidine; endodontics. 


\section{INTRODUCTION}

Calcium hydroxide $(\mathrm{CH})$ is used as intracanal dressing, because of excellent biologic and antimicrobial effects ${ }^{1}$. To facilitate the handling of the $\mathrm{CH}$, some vehicles have been proposed, providing different $\mathrm{pH}$ values and calcium ions release $\mathrm{e}^{2-4}$. Associations of $\mathrm{CH}$ with other antimicrobial substances, such as chlorhexidine (CHX) or camphorated paramonochlorophenol (CMPC) have also been evaluated ${ }^{5,6}$

CHX has a wide use as endodontic solution due to antimicrobial activity $^{7}$. Studies have suggested that $\mathrm{CHX}$ can be used in combination with $\mathrm{CH}$ to improve antimicrobial efficacy against resistant microorganisms to $\mathrm{CH}^{8-10}$. On the other hand, the combination of $\mathrm{CH}$ and $\mathrm{CMPC}$ was proposed to promote an antimicrobial synergistic effect against some facultative or anaerobic bacteria ${ }^{11}$. CMPC forms calcium para-chlorophenolate, which maintains a high $\mathrm{pH}$ and allows a controlled liberation of calcium and hydroxyl ions for a longer period ${ }^{4,12}$.

The efficiency of $\mathrm{CH}$ as intracanal dressing, in several chemical compositions, is attributed directly to the capacity of dissociating into calcium and hydroxyl ions, which promote alkalization over the root length around 120 days $^{3,13-15}$. However, this medication must be removed from the root canal for final obturation and it is a difficult procedure that routinely generates residues on the root dentin surface ${ }^{16-18}$. Some researches have reported that residues may negatively interfere on the endodontic treatment success and/or interact with endodontic sealers ${ }^{19}$. Moreover, if the temporary restoration, that seal the root canal from oral environment, failed or solubilize, the medication could be partially removed, decreasing the efficiency of $\mathrm{CH}$.

The clinical significance of the residues persistence is still controversial. The question whether the residues presence would present similar alkalizing potential and calcium ions release is still unsolved.

Therefore, the aim of this study was to evaluate the alkalizing potential and calcium ions release of residues from different dressings containing calcium hydroxide $(\mathrm{CH})$, associated to polyethylene glycol (Calen), polyethylene glycol with $0.4 \%$ chlorhexidine digluconate or CMPC with glycerin, when compared with root canal totally filled (positive control group) with $\mathrm{CH}$ or without any dressing (negative control group), in the periods of 24 hours, 7, 14 and 28 days. The null hypothesis was that there was no difference in the alkalinizing potential and calcium ions release, in the experimental periods.

\section{MATERIAL AND METHOD}

Fifty extracted human mandibular incisors with similar root canal anatomy and $16 \mathrm{~mm}$ length were selected and stored in $0.1 \%$ thymol. The root canals were endodontically instrumented with ProTaper System until F2 instrument (Dentsply, Maillefer). The root canals were irrigated with $2.5 \% \mathrm{NaOCl}$ (Cloro Rio, São José do Rio Preto, SP, BR). After the biomechanical preparation, the teeth were filled with 17\% EDTA (Biodinâmica Ind. Com., Ibiporã, PR BR) for 3 minutes, rinsed with $5 \mathrm{ml}$ of $2.5 \% \mathrm{NaOCl}$ and dried using absorbent paper points.

The specimens were randomly divided $(n=10)$ according to the intracanal dressings and filled using a lentulo spiral (Maillefer, Ballaigues, Switzerland). Radiographs were taken in buccolingual direction to confirm complete filling of the root canals:

$\mathrm{G} 1-(\mathrm{CH})$ : Calcium hydroxide with polyethylene glycol (Calen, SS White, São Paulo, SP, BR) at ratio of $2.5 \mathrm{~g}$ of calcium hydroxide, $1 \mathrm{~g}$ of zinc oxide, $0.05 \mathrm{~g}$ of colophony and $2 \mathrm{ml}$ of polyethylene glycol;

$\mathrm{G} 2-(\mathrm{CHC})$ : Calcium hydroxide with polyethylene glycol (Calen; SS White) and $0.4 \%$ chlorhexidine digluconate at ratio of $1.96 \mathrm{~g}$ paste to $0.04 \mathrm{ml}$ of $20 \%$ chlorexidine digluconate (Farmácia Arte e Ciência Araraquara, SP, BR), according to Silva et al. ${ }^{10}$;

G3-(HPG): Calcium hydroxide paste with camphorated paramonochlorophenol (Biodinâmica Ind. Com. Ltda, Ibiporã, PR, BR) and glycerin (SS White, São Paulo, SP, BR) at ratio of 1g: $0.5 \mathrm{ml}$ : $0.5 \mathrm{ml}$, according to Vianna et al. ${ }^{3}$;

$\mathrm{G} 4-(\mathrm{PC})$ : $\mathrm{CH}$ was maintained during all experiment, as positive control group;

G5-(NC): Without intracanal dressing inside the root canal, as negative control group.

The sealing of the roots was made with glass ionomer cement (Maxion R, FGM, Joinville, SC, BR), and an external waterproofing was applied as a temporary restoration on the cervical (Hidronorth, Londrina, PR, BR). Each specimen was immersed in $10 \mathrm{ml}$ of distilled water for 7 days. After this period, the temporary restoration was removed and the intracanal dressing was partially removed using F1 instrument (ProTaper System) in the total tooth length, except for the positive control group.

Each tooth was immersed in $1 \mathrm{ml}$ of distilled water and the specimens were placed inside new flasks with $10 \mathrm{ml}$ of distilled water after 24 hours, 7, 14 and 28 days. The distilled water was exchanged every analyzed period. $\mathrm{pH}$ measurements were performed directly in the solutions that the specimens were immersed, using the pHmeter DM 23 (Digimed, São Paulo, SP, BR) and pH electrode DME-CV1 (Digimed, São Paulo, SP, BR), both devices were calibrated at $25^{\circ} \mathrm{C}$, according to the manufacturer's instructions.

Calcium ions release was obtained using a calcium-ion selective meter with calcium-ion selective electrode (Q400I, Q838-Ca2, Quimis, Diadema, SP, BR). After calibration using $2 \mathrm{M}$ and $4 \mathrm{M}$ calcium chloride solutions (molecular weight of anhydrous calcium chloride $=110.98 \mathrm{~g} / \mathrm{mol}$ ), two reference points were established The ion-selective electrode was immersed in each specimen and the concentration $\mathrm{mg} / \mathrm{L}$ was obtained. The data of $\mathrm{pH}$ value and calcium ions release were submitted to ANOVA one-way and Tukey tests, at $5 \%$ significance.

In order to confirm the dressing residues presence, 3 teeth were randomly selected from each group and were longitudinally sectioned in the mesial-distal direction, and the buccal face was analyzed using a stereomicroscope, with magnification of $10 \mathrm{x}$ (Leica Microsystems, Germany). 


\section{RESULT}

The negative control group presented acid $\mathrm{pH}$ (6.10) in distilled water, and the calcium ions were not detected during all periods. The positive control presented alkaline $\mathrm{pH}$ (8.50) and calcium-ion presence in all periods. The means of $\mathrm{pH}$ and calcium ions release from experimental and control groups are described in Tables 1 and 2. The experimental groups did not differ among them regardless of the period, in both $\mathrm{pH}$ and calcium ions release evaluation ( $\mathrm{p}>0.05)$, however they presented lower values than positive control group $(\mathrm{p}<0.05)$ and higher values than negative control group $(\mathrm{p}<0.05)$.

Stereomicroscopy images showed the presence of residues from calcium hydroxide paste in the buccal face of the root canal, regardless of paste composition. Figure 1 shows the representative images of the calcium hydroxide residues on radicular dentin surface in the experimental and positive control groups.

Table 1. Mean and standard deviation of $\mathrm{pH}$ values of experimental and controls groups, at different periods

\begin{tabular}{cccccc}
\hline & CH & CHC & HPG & PC & NC \\
\hline $24 \mathrm{~h}$ & $6.17^{\mathrm{b}}(0.31)$ & $6.30^{\mathrm{b}}(0.28)$ & $6.97^{\mathrm{b}}(1.29)$ & $8.50^{\mathrm{a}}(0.25)$ & $6.10^{\mathrm{c}}(0.0)$ \\
7 days & $6.22^{\mathrm{b}}(0.24)$ & $6.09^{\mathrm{b}}(0.13)$ & $6.22^{\mathrm{b}}(0.13)$ & $8.31^{\mathrm{a}}(0.15)$ & $6.10^{\mathrm{c}}(0.0)$ \\
\hline 14 days & $6.22^{\mathrm{b}}(0.19)$ & $6.11^{\mathrm{b}}(0.22)$ & $6.22^{\mathrm{b}}(0.13)$ & $8.51^{\mathrm{a}}(0.10)$ & $6.10^{\mathrm{c}}(0.0)$ \\
28 days & $6.21^{\mathrm{b}}(0.14)$ & $6.10^{\mathrm{b}}(0.20)$ & $6.22^{\mathrm{b}}(0.16)$ & $8.58^{\mathrm{a}}(0.15)$ & $6.10^{\mathrm{c}}(0.0)$ \\
\hline
\end{tabular}

Different letters in the same line indicate significant differences between groups $(\mathrm{p}<0.05)$. CH - calcium hydroxide with polyethylene glycol; CHC - calcium hydroxide with polyethylene glycol and $0.4 \%$ chlorhexidine digluconate; HPG - calcium hydroxide with camphorated paramonochlorophenol and glycerin; PC - positive control and NC - negative control.

Table 2. Mean and standard deviation of calcium ion release $(\mathrm{mg} / \mathrm{l})$ of experimental and controls groups, in different periods

\begin{tabular}{cccccc}
\hline & CH & CHC & HPG & PC & NC \\
\hline $24 \mathrm{~h}$ & $2.79^{\mathrm{b}}(1.22)$ & $2.67^{\mathrm{b}}(1.71)$ & $3.42^{\mathrm{b}}(1.07)$ & $9.51^{\mathrm{a}}(0.02)$ & $0.00^{\mathrm{c}}(0.0)$ \\
7 days & $0.38^{\mathrm{b}}(0.83)$ & $0.78^{\mathrm{b}}(1.11)$ & $0.92^{\mathrm{b}}(0.97)$ & $7.37^{\mathrm{a}}(0.15)$ & $0.00^{\mathrm{c}}(0.0)$ \\
\hline 14 days & $1.39^{\mathrm{b}}(0.98)$ & $1.86^{\mathrm{b}}(1.29)$ & $1.48^{\mathrm{b}}(1.39)$ & $5.31^{\mathrm{a}}(0.25)$ & $0.00^{\mathrm{c}}(0.0)$ \\
\hline 28 days & $1.34^{\mathrm{b}}(1.14)$ & $1.82^{\mathrm{b}}(1.16)$ & $1.51^{\mathrm{b}}(1.17)$ & $4.52^{\mathrm{a}}(0.12)$ & $0.00^{\mathrm{c}}(0.0)$ \\
\hline
\end{tabular}

Different letters in the same line indicate significant differences between groups $(\mathrm{p}<0.05)$. CH - calcium hydroxide with polyethylene glycol; CHC - calcium hydroxide with polyethylene glycol and $0.4 \%$ chlorhexidine digluconate; HPG - calcium hydroxide with camphorated paramonochlorophenol and glycerin; PC - positive control and NC - negative control.

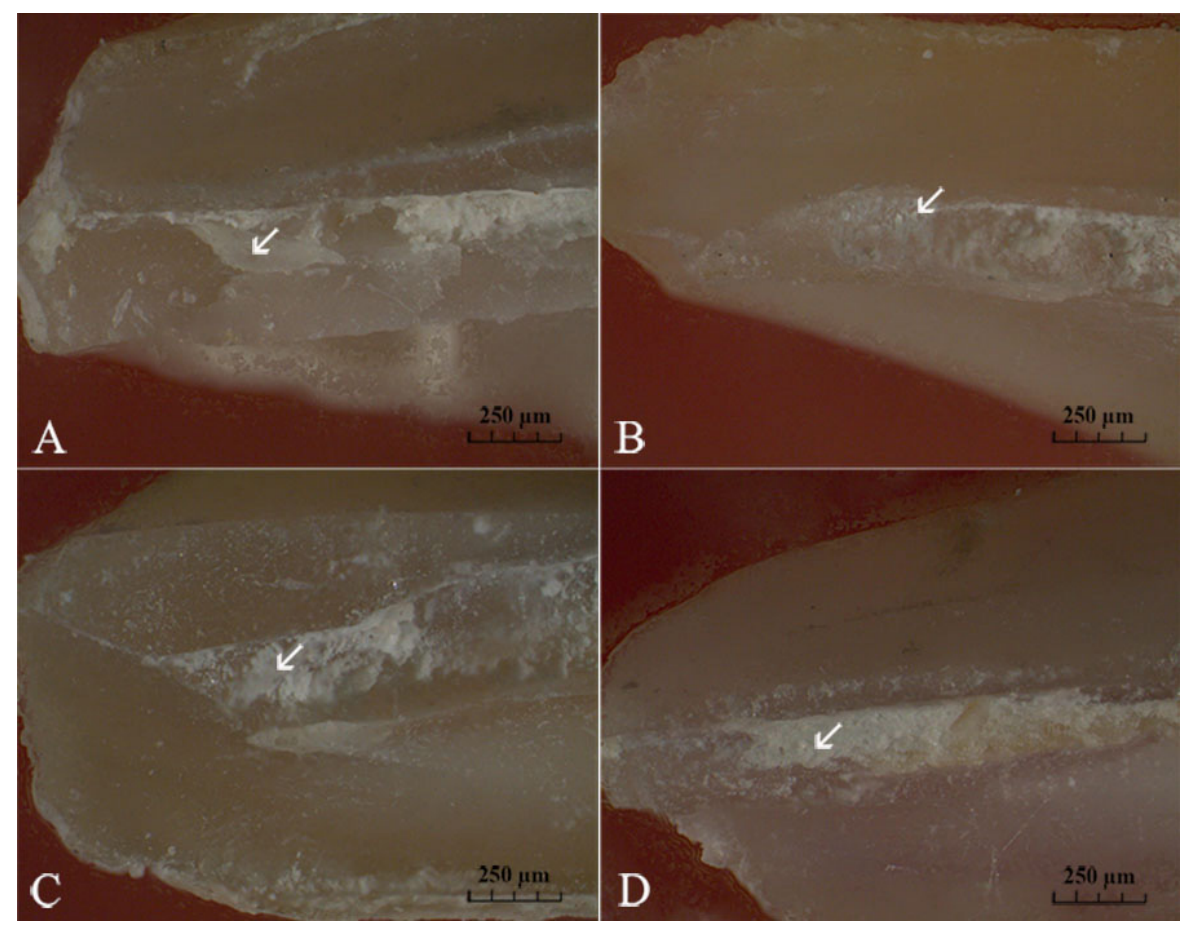

Figure 1. Representative stereomicroscopy images of experimental groups (10X): (A) G1 - calcium hydroxide with polyethylene glycol (CH); (B) G2- calcium hydroxide with polyethylene glycol and $0.4 \%$ chlorhexidine digluconate (CHC); (C) G3 - calcium hydroxide with camphorated paramonochlorophenol and glycerin (HPG) and (D) G4 - positive control (PC). White arrows show calcium hydroxide residues on radicular dentin. Scale: $250 \mu \mathrm{m}$. 


\section{DISCUSSION}

The null hypothesis was rejected, because the alkalinizing potential and calcium ion release of $\mathrm{CH}$ paste residues with polyethylene glycol $(\mathrm{CH}), \mathrm{CH}$ paste with polyethylene glycol associated with $0.4 \%$ chlorhexidine digluconate (CHC) or $\mathrm{CH}$ paste with $\mathrm{CMPC}$ and glycerin (HPG) were lower than positive control group (PC), in all periods. This study evaluated the residues effect on the alkalizing capacity and calcium ions release of intracanal dressings.

The efficiency of $\mathrm{CH}$ is due to chemical dissociation into calcium and hydroxyl ions in aqueous or viscous solutions ${ }^{13,20}$. The calcium ions participate in mineralization healing process and the hydroxyl ions promotes an alkaline osteogenic environment in the surrounding tissues ${ }^{15,21,22}$. When used as intracanal dressing has an effective alkalizing potential and provide calcium ion release $e^{4,22}$. However, after intracanal removal, frequently occurs persistence of $\mathrm{CH}$ residues on radicular dentin, mainly in the apical radicular third ${ }^{16,18}$.

In present study, the teeth length were standardized at $16 \mathrm{~mm}$ and instrumented until F2 instrument. This procedure aimed to standardize the root canal diameter, apical foramen and consequently the amount of $\mathrm{CH}$ dressing placed intracanal. After 7 days, the F1 instrument was purposely used to removal of $\mathrm{CH}$ dressing, in order to keep only residues in the root canals, which were confirmed by representative images made with stereomicroscopy.

The $\mathrm{pH}$ methodology, used in this study, is established in literature $e^{23,24}$. The atomic absorption spectroscopy is used to evaluate the calcium release of calcium hydroxide pastes ${ }^{23}$, but this method only quantified the calcium total present in sample ${ }^{24}$. Due to the ionized calcium participate in biological processes we used selective electrodes to calcium ions assessment ${ }^{21,22}$.
The results of the experimental groups were similar in all periods and presented lower $\mathrm{pH}$ values and calcium ions release than the positive control group. In relation to alkalizing potential, the intracanal residues of calcium hydroxide dressing were unable to promote alkalization of aqueous environment, possibly in function of the low disintegration $\mathrm{CH}$ residues, because of the root canal was maintained dry. Hosoya et al. ${ }^{25}$ observed that the alkalization potential of the mixtures with water were statistically quicker and greater than when the $\mathrm{CH}$ powder was used as intracanal dressing.

The overfilling of the root canal occurred in all samples, consequently, in $24 \mathrm{~h}$ period was detected calcium ions release, probably from residues present around of the radicular apex ${ }^{25}$. In another periods the calcium ions release was lower than $24 \mathrm{~h}$, possibly because the $\mathrm{CH}$ intracanal does not disintegrated and/or extruded to beyond to radicular apex. The positive control group (root canal filled with $\mathrm{CH}$ ) presented the highest calcium ions release, in accordance with Duarte et al. ${ }^{23}$.

Therefore, intracanal $\mathrm{CH}$ residues, regardless of the composition and/or mixture paste, do not induce the alkalization and calcium ions release. Further research focusing on the interaction of the residues with the filling of root canals are necessary in order to establish the possible interferences on the endodontic treatment prognosis.

\section{CONCLUSION}

The alkalizing potential and calcium ions release of residues from different intracanal dressings with $\mathrm{CH}$, during different experimental periods, were similar and significantly lower than the medication when it was maintained inside the root canal, encouraging the replacement if the temporary restoration fail.

\section{REFERENCES}

1. Siqueira JF Jr, Lopes HP. Mechanisms of antimicrobial activity of calcium hydroxide: a critical review. Int Endod J. 1999 Sep;32(5):361-9. http://dx.doi.org/10.1046/j.1365-2591.1999.00275.x. PMid:10551109.

2. Yücel AC, Aksoy A, Ertas E, Güvenç D. The pH changes of calcium hydroxide mixed with six different vehicles. Oral Surg Oral Med Oral Pathol Oral Radiol Endod. 2007 May;103(5):712-7. http://dx.doi.org/10.1016/j.tripleo.2006.10.016. PMid:17241800.

3. Vianna ME, Zilio DM, Ferraz CCR, Zaia AA, Souza-Filho FJ, Gomes BPFA. Concentration of hydrogen ions in several calcium hydroxide pastes over different periods of time. Braz Dent J. 2009;20(5):382-8. http://dx.doi.org/10.1590/S0103-64402009000500005. PMid:20126906.

4. Ferreira FBA, Souza PAS, Vale MS, Moraes IG, Granjeiro JM. Evaluation of $\mathrm{pH}$ levels and calcium ion release in various calcium hydroxide endodontic dressings. Oral Surg Oral Med Oral Pathol Oral Radiol Endod. 2004 Mar;97(3):388-92. http://dx.doi.org/10.1016/j.tripleo.2003.08.020. PMid:15024365.

5. Ercan E, Dalli M, Dülgergil CT. In vitro assessment of the effectiveness of chlorhexidine gel and calcium hydroxide paste with chlorhexidine against Enterococcus faecalis and Candida albicans. Oral Surg Oral Med Oral Pathol Oral Radiol Endod. 2006 Aug;102(2):e27-31. http:// dx.doi.org/10.1016/j.tripleo.2006.02.022. PMid:16876041

6. Siqueira JF Jr, Magalhães KM, Rôças IN. Bacterial reduction in infected root canals treated with $2.5 \% \mathrm{NaOCl}$ as an irrigant and calcium hydroxide/camphorated paramonochlorophenol paste as an intracanal dressing. J Endod. 2007 Jun;33(6):667-72. http://dx.doi.org/10.1016/j. joen.2007.01.004. PMid:17509403.

7. Gomes BPFA, Ferraz CCR, Vianna ME, Berber VB, Teixeira FB, Souza-Filho FJ. In vitro antimicrobial activity of several concentrations of sodium hypochlorite and chlorhexidine gluconate in the elimination of Enterococcus faecalis. Int Endod J. 2001 Sep;34(6):424-8. http:// dx.doi.org/10.1046/j.1365-2591.2001.00410.x. PMid:11556507.

8. Zehnder M, Grawehr M, Hasselgren G, Waltimo T. Tissue-dissolution capacity and dentin-disinfecting potential of calcium hydroxide mixed with irrigating solutions. Oral Surg Oral Med Oral Pathol Oral Radiol Endod. 2003 Nov;96(5):608-13. http://dx.doi.org/10.1016/ S1079-2104(03)00157-4. PMid:14600697. 
9. Sirén EK, Haapasalo MP, Waltimo TM, Ørstavik D. In vitro antibacterial effect of calcium hydroxide combined with chlorhexidine or iodine potassium iodide on Enterococcus faecalis. Eur J Oral Sci. 2004 Aug;112(4):326-31. http://dx.doi.org/10.1111/j.1600-0722.2004.00144.x. PMid:15279651.

10. Silva RAB, Leonardo MR, Silva LAB, Faccioli LH, Medeiros AI. Effect of a calcium hydroxide-based paste associated to chlorhexidine on RAW 264.7 macrophage cell line culture. Oral Surg Oral Med Oral Pathol Oral Radiol Endod. 2008 Nov;106(5):e44-51. http://dx.doi. org/10.1016/j.tripleo.2008.06.027. PMid:18718793.

11. Siqueira JF Jr, Uzeda M. Disinfection by calcium hydroxide pastes of dentinal tubules infected with two obligate and one facultative anaerobic bacteria. J Endod. 1996 Dec;22(12):674-6. http://dx.doi.org/10.1016/S0099-2399(96)80062-8. PMid:9220753.

12. Alencar AHG, Leonardo MR, Silva LAB, Silva RS, Ito IY. Determination of the p-monochlorophenol residue in the calcium hydroxide + p-monochlorophenol combination used as an intracanal dressing in pulpless teeth of dogs with induced chronic periapical lesion. J Endod. 1997 Aug;23(8):522-4. http://dx.doi.org/10.1016/S0099-2399(97)80314-7. PMid:9587324.

13. Bystrom A, Claesson R, Sundqvist G. The antibacterial effect of camphorated paramonochlrophenol, camphorated phenol and calcium hydroxide in the treatment of infected root canal. Endod Dent Traumatol. 1985 Oct;1(5):170-5. http://dx.doi.org/10.1111/j.1600-9657.1985. tb00652.x. PMid:3865763.

14. Mohammadi Z, Dummer PM. Properties and applications of calcium hydroxide in endodontics and dental traumatology. Int Endod J. 2011 Aug;44(8):697-730. http://dx.doi.org/10.1111/j.1365-2591.2011.01886.x. PMid:21535021.

15. Tronstad L, Andreasen JO, Hasselgren G, Kristerson L, Riis I. pH changes in dental tissues after root canal filling with calcium hydroxide. J Endod. 1981 Jan;7(1):17-21. http://dx.doi.org/10.1016/S0099-2399(81)80262-2. PMid:6938618.

16. Kuga MC, Tanomaru-Filho M, Faria G, Só MV, Galletti T, Bavello JR. Calcium hydroxide intracanal dressing removal with different rotary instruments and irrigating solutions: a scanning electron microscopy study. Braz Dent J. 2010;21(4):310-4. http://dx.doi.org/10.1590/S010364402010000400004. PMid:20976380.

17. Kuga MC, Campos EA, Faria-Junior NB, Só MV, Shinohara AL. Efficacy of NiTi rotary instruments in removing calcium hydroxide dressing residues from root canal walls. Braz Oral Res. 2012 Jan-Feb;26(1):19-23. http://dx.doi.org/10.1590/S1806-83242012000100004. PMid:22344333.

18. Faria G, Viola KS, Kuga MC, Garcia AJ, Daher VB, Leonardo MFP, et al. Effect of rotary instrument associated with different irrigation techniques on removing calcium hydroxide dressing. Microsc Res Tech. 2014 Aug;77(8):642-6. http://dx.doi.org/10.1002/jemt.22382. PMid:24844676.

19. Ricucci D, Langeland K. Incomplete calcium hydroxide removal from the root canal: a case report. Int Endod J. 1997 Nov;30(6):418-21. http://dx.doi.org/10.1111/j.1365-2591.1997.tb00734.x. PMid:9588983.

20. Kuga MC, Duarte MA, Sant'Anna-Júnior A, Keine KC, Faria G, Dantas AA, et al. Effects of calcium hydroxide addition on the physical and chemical properties of a calcium silicate-based sealer. J Appl Oral Sci. 2014 Jun;22(3):180-4. http://dx.doi.org/10.1590/1678-775720130032. PMid:25025558.

21. Seux D, Couble ML, Hartmann DJ, Gauthier JP, Magloire H. Odontoblast-like cytodifferentiation of human dental pulp cells in vitro in the presence of a calcium hydroxide-containing cement. Arch Oral Biol. 1991;36(2):117-28. http://dx.doi.org/10.1016/0003-9969(91)90074-5. PMid:2059161.

22. Calt S, Serper A, Ozçelik B, Dalat MD. pH changes and calcium ion diffusion from calcium hydroxide dressing materials through root dentin. J Endod. 1999 May;25(5):329-31. http://dx.doi.org/10.1016/S0099-2399(06)81165-9. PMid:10530255.

23. Duarte MAH, Midena RZ, Zeferino MA, Vivan RR, Weckwerth PH, Santos F, et al. Evaluation of pH and calcium ion release of calcium hydroxide pastes containing different substances. J Endod. 2009 Sep;35(9):1274-7. http://dx.doi.org/10.1016/j.joen.2009.05.009. PMid:19720230.

24. Santos AD, Moraes JC, Araújo EB, Yukimitu K, Valério Filho WV. Physico-chemical properties of MTA and a novel experimental cement. Int Endod J. 2005 Jul;38(7):443-7. http://dx.doi.org/10.1111/j.1365-2591.2005.00963.x. PMid:15946264.

25. Hosoya N, Takahashi G, Arai T, Nakamura J. Calcium concentration and $\mathrm{pH}$ of the periapical environment after applying calcium hydroxide into root canals in vitro. J Endod. 2001 May;27(5):343-6. http://dx.doi.org/10.1097/00004770-200105000-00009. PMid:11485253.

\section{CONFLICTS OF INTERESTS}

The authors declare no conflicts of interest.

\section{${ }^{*}$ CORRESPONDING AUTHOR}

Kamila de Figueiredo Pereira, UNESP - Universidade Estadual Paulista, Faculdade de Odontologia de Araraquara, Departamento de Odontologia Restauradora, Rua Humaitá, 1680, 14801-903 Araraquara - SP, Brasil, e-mail: kamilafpereira@hotmail.com 